\title{
Argentine Literature as Part of the Latin-American: Debates, Characteristics and Dialogues
}

\author{
LUCÍA CAMINADA ROSSETTI
}

\begin{abstract}
The article will suggest that the texts and ways of reaching some materials and perspectives in Argentina, remains at a national level. It is important to notice that in order to read criticism and theory regarding Latin American literature, Spanish from Río de la Plata separates at some point the fields. In that regard, one of the greatest assets and achievements of Argentinian literary research concerns the relationship between politics and fiction. In connection with this it might be asked how we can think of Argentinian literature without linking it to the social discourse? How can we think of the comparative field of Latin-American and Argentinian literature as one academic area of studies? In our view, comparatism seems to be one of the loneliest areas of studies in terms of the fields of theory, fiction and criticism. We thus suggest that in Argentina, literary research and criticism in general are strictly concerned with only one option: the national culture. Thus, exclusively, western theoretical frames are chosen to read literature and comparative perspectives are mostly applied to European studies. That is why I insist on the fact that comparative literary research is not represented institutionally at all.
\end{abstract}

Keywords: Latin America; Argentine literature; comparative literature; cultural studies

\section{Introduction}

How do we think of the comparative field of Latin-American and Argentinian literature as one and the same academic area of studies? In our view, comparative literature in Latin America seems to be one of the loneliest areas of study in terms of theory, fiction and criti-cism. As García Canclini has argued: "Can we really think about one Latin American subject as totalizing and unique?” (2001). He replies that the problem is to declare a monolithic iden-tity as legitimate in the romantic self of the modern individual. Instead, he insists, there is an unstable identity, dissimilar and oscillating. A prior fact to be taken into consideration may be to assume heterogeneity, variety and hybridity in order to overcome nationalism. 
How do we read Argentinian literature as part of the Latin-American one? The main trends of Argentinian national literary theory and academic literary criticism nowadays are concerned with archives, memory and unknown documents related to its writers. In the same order, there is a tendency to explore the field of regional literatures.

When I first thought about the title of this article, there was a question, kind of a simple one: How do we read Argentinian literature as part of the Latin-American one? Then, moving towards the contextualization of the subject, I realized that I would need to explain at least two basic facts in order to think about how we read or think of Argentinian literature as part of the Latin American one:

1) What is Argentina as a discourse? And what about its literature? This is the first issue to be defined.

2) When we refer to Latin-American literature: what would we be thinking of or what would be the aspects to be considered in order to open the dialogue?

The first question can be answered in a number of ways. But let us take the simplest one, an image: the end of the world. Literally, we are over there in the world map, at the very end. There is one image that is used as the initial metaphor that expresses the Nation: the desert of the pampa. The poetics of the desert is directly related to loneliness, expanse of the land and hostility. In the past, the Conquistadors considered our land a failure (Pizarro 1997): no treasure, nomad tribes in general, nothing more than a plain land, apart from the cultures living on its frontiers. Who cared about the exotic scenery when there was only a monotonous landscape to be seen? That's the pampa.

From this image the country's first intellectuals in the $19^{\text {th }}$ century started tracing a national literature (ignoring plenty of other realities that could be represented) and they privileged the landscape of the pampa and the figure of the gaucho, the latter playing the role of the courageous male hero who uses violence in order to confront different challenges (Montaldo 1993).The other metaphor when thinking of national literature was the frontier. By then, it was representing the other image of violence: rape, wars and captivity.

Later, immigrants came in massive waves to settle in Argentina. From all over the world, but particularly from Europe. This fact reaffirmed the eurocentrism already present in the cultural discourse. Beatriz Sarlo in Una modernidad periférica: Buenos Aires 1920 y 1930 (1988) notes that modernization was related to a period of technology, progress, and also social difference started to be visualized in the intellectual panorama. 
Argentine Literature as Part of the Latin-American: Debates, Characteristics and Dialogues

When suggesting that Argentina's literature remains at a national level, it is important to notice that in order to read criticism and theory in Argentina, the models are translated from the European frames. It must be taken into consideration that our native language (the Argentinian Spanish from the River Plate zone) separates Argentina and Uruguay, at some point, from the global Hispanic world. This small area of south America (Uruguay and Argentina) is culturally isolated from the concept of Latin America.

One of the strongest assets and achievements of Argentinian literary research is the relationship between politics and fiction (Piglia; Viñas; Sarlo). This is the result of the process of modernization and literature becoming a channel to connect reality and possibilities, perspectives and points of views to be told. In connection with this it might be asked: how do we think of Argentinian literature without linking it to the social discourse?

A possible answer is what Beatriz Sarlo and Ricardo Piglia and many other critics have pointed out, that politics and fiction are the basis of the construction of the literary system. One reason for this is that in Argentina, literary research and criticism in general are still strictly concerned with national culture and comparative literary research is not represented institutionally at all when analyzing Latin American texts. The first step might be to open the doors to the dialogue with Latin American theories and debates because the main trends of national literary theory and criticism today are mostly concerned with archives, memory and unknown documents related to Argentinian writers. Similarly, there is a tendency to explore the field of the regional literatures but focusing on small areas and corpus.

The second question is closely related to the Latin American thought and philosophy, as it is a system to read cultural and social discourses, in which literature of course is included. In most of the countries of America (I include the US and Canada as well) the so-called Latin American studies point to discourse in its ideological aspects as linked to different alternatives to construct a multicultural and anticolonial approach.

Furthermore, in 1910 in Latin America, modernism was related to different intellectual manifestations. Especially in Chile, Argentina and Uruguay, the modernizing process was particularly rapid. European literary theories were adapted to local needs (Rama 1982:12). Later, in the 1930s, social class and expressions would become part of literature as well. For this reason, internal tensions in Latin American societies regarding literature and society were and still are part of the cultural discussion. As Rama puts it:

La ubicación de la producción literaria, como coronación de las tradiciones creativas constantes que se han cumplido en las subculturas americanas, 
conduce a una doble lectura de tipo intertextual: la de los textos literarios y la del discurso que se fragua en las diversas culturas testimoniando la tarea colectivas de los hombres, con una tercera lectura crítica sobre las estrechas conexiones entre ambos procesos. Relaciones que ya no podrán establecerse entre la literatura vista como un bloque homogéneo, por una parte, y la sociedad latinoamericana concebida como un todo indistinto por la otra, tal como la practica habitualmente la crítica, sino como conexiones entre precisos y determinados sectores de esa sociedad (1982: 14-15)

Néstor Garcia Canclini, Ángel Rama, Leopoldo Zea, Antonio Cornejo Polar, Paulo Freire and others are some of the most important intellectuals who have adopted this approach. In Argentina, Manuel Ugarte, Juan José Hernández Arregui and Rodolfo Kusch for example are some of the critics thinking the text is connected with social issues. Nevertheless, their studies are a minority or more related to the regional or social studies. A theoretical approach is very rare. The tensions between national and continental approaches appeared in the period between 1960 and 1990 .

I will try to define some of the main concepts that were formulated from Garcia Canclini's point of view. According to the Latin American studies, plurality and heterogeneity are the main characteristics of culture. Some minor, marginal and ethnic literatures are the ones being revalorized. Notions related to Transculturation, as with Ángel Rama, the Otherness Literature (Bendezu), Diglosic Literature (Ballón), and Alternative Literature (Lienhard) at some point all converge in what García Canclini considers heterogenic literature and hybrid culture. Walter Mignolo has questioned the concept of literature itself, taking into consideration social, political and cultural aspects than cannot be avoided such as the ethnical mixture, the multiple languages, the colonization process that characterized the discourse (he prefers to refer to discourse and not to literature, arguing that the oral aspects are not included in the field).

The complex and conflicting identities of Latin America can be considered together with the obsession of those nations to define their identity around the idea of patriotism. I will explain now, briefly, some characteristics, dialogues and debates that contribute to the reflection on the relative complexity of incorporating the comparatist focus into these kind of studies.

\section{Characteristics}

Generally speaking, Argentinian literature has been read (critically) from the point of view of the French and other Eurocentric perspectives. The same thing can be said for fiction. In terms of academic studies, it is like we translate the theoretical aspects of sociology and philosophy to the study of literature. 
Argentine Literature as Part of the Latin-American: Debates, Characteristics and Dialogues

Another point worth mentioning is that since the $19^{\text {th }}$ century - when literature started to be studied from its national aspect - the model of Saint-Simon and the romantic ideas of the generation of 1837 were to be superimposed over or directly transferred to national literature. In the $21^{\text {st }}$ century sociology, Marxism, psychoanalysis, structuralism and poststructuralism permeate the study of Argentinian literature.

Angel Rama, the Uruguayan latinoamericanist, has said that a lettered culture (cultura letrada) comes from a lettered city. This is what can properly define Argentinian literature, built from the eurocentrism of rural figures and characters, written by white and lettered intellectuals. Rama has shown how the internationalism of the modernization period (1870-1910) pointed toward a regional model ( $19^{\text {th }}$ century), with the purpose of re-establishing the patriotic myth. Only with romanticism and realism in the $19^{\text {th }}$ century, the individual talents started to emerge. Rama defines transculturation as a concept that includes two main aspects: on the one hand, it registers the present culture of Latin American communities (which are supposed to be already transculturated and in permanent evolution) and their characteristics are mainly coming from idiosyncratic values; on the other hand, it can be seen as a continuous creative system.

From Josefina Ludmer's point of view in El género gauchesco. Un tratado sobre la patria (1988), Argentinian writers (particularly the ones of the $19^{\text {th }}$ and $20^{\text {th }}$ centuries) take the voice of otherness (the gaucho, for example) and reinvent it from the cultured intellectual's perspective, at the same time evoking dreamlike idyllic and bucolic landscapes and lifestyles ascribed to the pampa.

\section{Debates}

In The Argentina Reader: History, Culture, Politics, Graciela Montaldo and Gabriela Nouzeilles suggest that the reason why Argentinian literature is different in terms of representation is that in the colonial period it was poor. Such literature dealt with the social reality and politics.

The pampa was the symbol of national literature at the beginning of the $19^{\text {th }}$ century, as written by the Romantics. The plain and empty land is the first literary metaphor in the national context. As Graciela Montaldo has said, this space produced a genre, the gauchesca, the gaucho being its hero.

The main debate that underlies the Argentinian corpus is the one founded by Sarmiento: civilization or barbarism? From his house in the country, Sarmiento (who had never been to Buenos Aires), promoted the "civilized" urban, progressive and modern life of the organized cities. The other (the native, the gaucho and the immigrant mostly) were only represented as a folkloric aspect 
of literature, incarnating the values that the nation must fight against. In the $20^{\text {th }}$ century, Borges and some other writers with the creole (criollismo) invented the myths of these barbaric figures as heroes, following always the European models like the Greek heroes, for example.

Rama distinguished literature that was produced by the urban sector from a transnational frame of modernity. This space can be defined as cultura letrada, the lettered culture. This lettered space was confronted by regionalism and indigenismo. It is possible to identify rural or regional literature as transcultural literature that does not belong to the mainstream.

\section{Dialogues}

To talk about the possible dialogues between Argentina and Latin America in terms of the literary field, perhaps the most evident manifestation was the Latin American Boom. What was this exactly? As Ángel Rama has noted, it appeared first - and mostly - in Buenos Aires and México around the 1960. 1967 was a glorious year for Latin American literature: the Nobel Prize was awarded to the Guatemalan M. A. Asturias, while G. G. Márquez’s One Hundread Years of Solitude was published and Julio Cortázar's Hopscotch had already been on the market since 1963, with 3,000 copies and it was the first book to be re-published and a real success in terms of sales.

According to Angel Rama, the Latin American Boom can be viewed in three ways: as a market strategy, an expansion of Latin American literature and a great possibility for intellectuals to be together and to spread leftist ideologies. The Peruvian writer, Mario Vargas Vargas Llosa declared that the boom was a random group of writers who were recognized by the critics. Each critic had his own list. For Vargas Llosa, the boom was an historical accident because editors took advantage of the situation to promote Latin American literature. For Cortázar, the boom was positive because of the expansion of the reading public and the spreading of leftist ideas. He insists that rather than the product of the editors and a consumerist thing, the boom might instead be thought of as a phenomenon made by readers. He associates readers with the "pueblo latinoamericano", the common readers as opposed to the cultural elite.

What has been called the boom of Latin American literature seems to me a formidable support for the present and future cause of socialism, that is, the march of socialism that I consider inevitable and not in a too distant future. Finally, what is the boom but the most extraordinary awareness by the Latin American people of a part of their own identity? Cortázar interprets the phenomenon as a massive popular support to the cause of Latin American socialism. 
Argentine Literature as Part of the Latin-American: Debates, Characteristics and Dialogues

In conclusion, as Mabel Moraña (1997) has said, there is still a field of Latin American studies that must go deeply into the River Plate's intellectual space. If literary tradition is mutable despite certain facts that consecrate it, there are literary heterodoxies beyond dogmas. Subsequently, these heterodoxies belong to the same identification process and tradition. Complexities in these matters should be taken into account.

\section{Lucía Caminada Rossetti \\ lucia.caminada@gmail.com \\ Universidad Nacional del Nordeste \\ ARGENTINA}

\section{Bibliogaphy}

Anderson Imbert, E. 1976. El realismo mágico y otros ensayos. Caracas: Monte Avila.

Cornejo Polar, A. 1987. La literatura latinoamericana y sus literaturas regionales y nacionales como totalidades contradictorias". - A. Pizarro, coord., Hacia una historia de la literatura latinoamericana. México: El Colegio de México/Universidad Simón Bolívar, 123-132.

Cornejo Polar, A. 1994. Escribir en el aire. Ensayo sobre la heterogeneidad cultural en las literaturas andinas. Lima: Editorial Horizonte.

Cornejo Polar, A. 1997. Mestizaje e hibridez: el riesgo de las metáforas. - Revista Iberoamericana, LXIII/180, July-September, 341-344. https://doi.org/10.5195/ REVIBEROAMER.1997.6197

García C. 2001. Culturas híbridas. Estrategias para entrar y salir de la modernidad. Mexico : Penguin Random House.

Ludmer, J. 1988. El género gauchesco. Un tratado sobre la patria. Buenos Aires: Sudamericana.

Montaldo, G. 1993. De pronto, el campo. Literatura argentina y tradición rural, Rosario: Beatriz Viterbo Ed.

Montaldo, G., Nouzeilles, G. 2002. The Argentina reader: history, culture, politics. Durham and London: Duke University Press

Moraña, M. 1997. Introducción. - Ángel Rama y los estudios latinoamericanos. Pittsburgh: Pittsburgh University Press, 7-24.

Mignolo, W. 1986. Ficcionalización del discurso historiográfico. - S. Sosnowski, comp., Augusto Roa Bastos y la producción cultural. Buenos Aires: Folios Ediciones, 197-209.

Piglia, R. 1990. Crítica y ficción. Buenos Aires: Siglo Veinte.

Pizarro, A., coord. 1985. Introducción. - La literatura latinoamericana como proceso. Buenos Aires: Centro Editor América Latina.

Rama, Á. 1982. Los gauchipolíticos rioplatenses. Buenos Aires: Centro Editor América Latina. 
CAMINADA ROSSETTI

Rama, Á. 1984. La ciudad letrada. Hanover, Ediciones del Norte.

Rama, Á. 2007. Transculturación narrativa en América Latina. Buenos Aires: El Andariego Ed.

Sarlo, B. 1988. Una modernidad periférica: Buenos Aires 1920 y 1930. Buenos Aires: Nueva Visión.

Schwartz, J. 1991. Las vanguardias latinoamericanas. Madrid: Cátedra.

Viñas, D. 1982. Literatura argentina y realidad política. Buenos Aires: Centro Editor de América Latina. 